\title{
TJBF FINANCIAL LIBERALIZATION OR FINANCIAL DEVELOPMENT? TESTS USING DELPHI-BASED INDEX OFLIBERALIZATION
}

\author{
Nicolaas Groenewold, Jiangang Peng, Guanzheng \\ Li and Xiangmei Fan \\ University of Western Australia, Hunan University \\ and Hunan Normal University
}

\begin{abstract}
Most empirical analysis of the finance-growth nexus has used measures of financial development such as the ratio of monetary or financial assets to GDP to measure financial development. We argue that from a policy perspective measures of financial liberalisation or reform are of greater interest and, besides, are less likely to be beset by endogeneity problems which have dogged the empirical growth literature. We develop such a measure by combining the 'Delphi' method and principal components analysis to construct an index of financial liberalisation for China. Much of China's financial development has been policy-driven and we could expect to find a distinct difference, at least in timing, between measures of financial reform and financial development. We compare our financial liberalisation index to a number of standard measures of financial development and find that there is pervasive evidence that financial liberalisation Granger-causes financial development but not vice versa.
\end{abstract}

Keywords: financial liberalisation, financial development, economic growth JEL classification: G18, O16, O43, O53

\section{Introduction}

Empirical research on the determinants of economic growth has shown a resurgence over the past decade or so. A recent strand of this literature focuses on the relationship between finance and growth. It, too, has expanded rapidly over the past decade - a recent survey by Levine (2005) lists about 300 references, most of which have appeared since the late 1990s. The continuing lively research activity in this area of investigation attests to the importance of the questions: 
why is it that some countries have grown quickly over long periods while others have stagnated, and can policy be designed to stimulate the growth process?

The policy question has been particularly important for the finance and growth strand of the literature since there has been a rapid development of the financial systems of a number of developing countries fuelled, partly at least, by government policy which has freed up financial systems previously subject to pervasive regulations. We would argue, however, that much of the literature has been only indirectly relevant to the policy questions which have often motivated it since the explanatory variables in growth regressions have typically been measures of financial development which, in contrast to measures of financial liberalisation, are one step removed from policy. Thus Levine (2005) in the theoretical section of his survey paper sets out to "describe models where market frictions motivate the emergence of distinct financial arrangements [which] ... may influence economic growth" (p.869). ${ }^{1}$ The emphasis is therefore clearly on (endogenous) developments in financial markets and their effects on economic growth.

The empirical literature generally follows this line and uses measures of financial development. The pioneering work of Goldsmith (1969), for example, used measures of the size of the financial sector such as the ratio of assets of financial intermediaries to GDP to proxy the state of financial development. Subsequent research has generally followed this lead although with variations. Thus an influential paper in the 1990s, King and Levine (1993a), use not only the ratio of financial institutions' assets to GDP as a measure of the extent of financial intermediation but also attempt to include a measure of the importance of the private sector both in providing and in using funds. Other work included measures of the importance of the stock market such as the ratio of stock market turnover or capitalisation to GDP; see, e.g., Levine and Zervos (1998a).

The experience of the Chinese economy has also provided data for the analysis of the relationship between finance and growth and, although the literature using these data is rather limited, similar variables have been used. Two early (and similar papers) by Li and Liu (2001) and Liu and Li (2001) examine the relationship between "financial liberalisation and growth in China's economic reform" by regressing aggregate GDP growth on investment growth disaggregated into four components according to the source of funding, the argument being that the source of funding has changed with the development of the financial system so that it provides (indirect) evidence about the effect of such development on growth. They conclude that a shift from state appropriation to self-raised funds has stimulated economic growth, providing evidence of the positive effects of development on growth.

More recent papers include those by Allen et al. (2005), Hao (2006) and Liang and Teng (2006). Of these, the last two both directly address the financegrowth question, the former using a panel of provincial data and the latter

\footnotetext{
${ }^{1}$ A recent exception is the paper by Bekaert, Harvey and Lundblad (2005) which focuses on liberalisation but restricts its attention to the equity market.
} 
aggregate time-series data. Liang and Teng use traditional financial development measures representing bank credit and the deposit/liability ratio while Hao argues that such measures tell only part of the story and finds that the financing method (the switch from state budget appropriations to loans as in Liu and $\mathrm{Li}$ above) and the volume of saving are more powerful determinants. Hao concludes that "the development of financial intermediation exerts a positive, causal and economically large impact on China's economic growth" (361) while the results in the paper by Liang and Teng are more ambiguous: there is no causation from financial development to growth but some evidence that causation runs in the opposite direction.

Thus, on the whole, the finance-growth literature has used measures of financial development rather than of financial liberalisation. We argue that this has two disadvantages. Both are related to the fact that financial development results not only from policy changes designed to enhance the functioning of the financial system but also from the interaction of policy (and indeed the financial system itself) with the rest of the economy. It is therefore difficult to link the results of empirical work directly to policy. Moreover, it is likely that financial development measures are generally endogenous in an econometric sense making it difficult to interpret regression results in cause-and-effect terms, a problem that has dogged the empirical growth literature in general. Neither of these disadvantages are likely to be as severe for measures of financial liberalisation which more closely reflect the policy changes driving the development of the financial system. On the other hand, it is, of course, true that financial development will be broader than financial liberalisation and will capture events which are not policy-driven but will nevertheless have an important influence on the ability of the financial system to support economic growth. Thus, while we think there is a case for redressing the balance in favour of financial liberalisation, we do not wish to make exclusivist claims.

Our aim in this paper is quite modest - we do not set out to re-examine all questions in terms of financial liberalisation which have previously been analysed using measures of financial development. Rather, we provide a detailed explanation of the construction of a financial liberalisation index for China and briefly compare it to some common measures of financial development. We choose China as our case study since it is relatively under-researched and, more importantly, because the pace of financial deregulation in China since the onset of reforms in 1978 has been rapid and sustained so that, here of all places, we may to observe a clear difference between measures of financial development and liberalisation which might be difficult to distinguish for countries where the pace of reform has been slower.

The contribution of this paper is, therefore, that we (a) construct an index of financial liberalisation, (b) compare it to more common measures of financial development and, in so doing, (c) provide a reasonably detailed account of financial reforms in China since the beginning of economic reforms and 'opening-up' under Deng Xiaoping in 1978. We conclude that for China during this period, at least, there is a clear distinction between the liberalisation 
index and measures of financial development and, in particular, that financial liberalisation Granger causes the three measures of financial development we use but that the causation does not run in the opposite direction.

The structure of the paper is as follows. In section 2 we provide background information on the recent reforms of the Chinese financial system; in section 3 we explain the construction of our financial liberalisation index and in section 4 we compare it to some common measures of financial development using Granger causality analysis. Conclusions are presented in the final section.

\section{A brief history of financial system reform in China since 1978}

Economic reform has proceeded apace since reform and 'opening-up' began in 1978 and financial deregulation has been a central part of this reform. Financial liberalisation has been continual and widespread since 1978 and in this section we present a brief survey of the main aspects under seven headings: the diversification of financial institutions, the reform of credit quotas, interest rate deregulation, the establishment of a financial regulatory system, the development of a stock market, increased openness to the rest of the world, and the development of the financial legal framework. ${ }^{2}$

\subsection{Institutional diversification}

The development of greater diversity in financial institutions can be characterised as having taken place in four stages: (i) the development of a two-tier banking system (1979-93), (ii) the establishment of the three policy banks and the commercialisation of the four state-owned banks (1994-97), (iii) the management of non-performing loans and financial restructuring (1997-2001) and, (iv) the opening of the financial system to the rest of the world and increased privatisation (2001 to the present). We discuss each of these stages in turn.

The first stage saw the development of the two-tier banking system, beginning in 1979 when the Agriculture Bank of China, the Bank of China and the Construction Bank were established as state-owned specialised banks and the China International Trusted Investment Companies (CITIC) emerged to target international financial investment. In the same year, the first urban credit cooperative (UCC) was set up to meet the financial needs of the urban non-state sector that was not well served by the state-owned special banks. Subsequently, the growth of the UCCs surged with official acceptance and the rapid development of the non-state sector of the economy.

In 1984 the State Council designated the People's Bank of China (PBC) as the central bank, and also established the Industrial and Commercial Bank, the fourth state-owned specialised bank, to take over the deposit-taking and lending functions of the PBC. Between 1985 and 1992, the Chinese government

${ }^{2}$ These correspond to the first seven of eight aspects covered by our financial liberalisation index, the last aspect of which is a general policy variable not covered as a specific heading below. 
fostered increased competition by permitting the establishment of new small- and medium-sized commercial shareholding banks, which initially offered banking services to households and firms, mainly in the regions and cities. This group included the Bank of Communication (1986), the Shenzhen Development Bank (1987), the CITIC Industrial Bank (1987), the China Merchants Bank (1987), the Guangdong Development Bank (1988), the Fujian Industrial Bank (1988), China Everbright Bank (1992), the Hua Xia Bank (1992) and the Pudong Development Bank (1993).

The second stage of institutional diversification covered the period 1994 to 1997. It centred around the establishment of the three policy banks and the accelerated commercialisation of the four state-owned special banks. Three policy banks were set up in 1994 to separate policy lending from commercial banking activities, with the policy lending allocated to the policy banks. In addition, to create a more competitive commercial banking sector, the shareholding banks, the city commercial banks (CCBs) and the Rural Credit Cooperatives (RCCs) were allowed to develop quickly during this period. The first shareholding bank funded completely by private capital, the Minsheng Bank, was also set up during this stage. Most of the UCCs set up during the previous stage were reorganised into a smaller number of CCBs. The RCCs have, in turn, undergone consolidation since 1996.

During the third stage of institutional diversification, attention was devoted to the growing problem of non-performing loans (NPLs) in the Chinese banking system, which had increased to alarming proportions by 1997. In response to increased concern, the government set up four Asset Management Companies in 1998 to deal with the bad assets of the four state-owned commercial banks and recapitalised them with an injection of 270 billion yuan. In addition, in November 2001 the PBC approved the consolidation of 1,658 RCCs into 81 joint stock city or rural commercial banks depending on the assessment of assets and capital, writing off some bad debts, and encouraging new shareholders. This reorganisation was part of a pilot reform of the rural financial system. Other reform measures during this period included the closure and bankruptcy of several insolvent financial institutions including the Hainan Development Bank and three trust and investment companies which had become highly insolvent and were closed in 1997-1998.

The fourth stage consists of the continuing privatisation of the financial sector and the opening of the financial industry to the rest of the world. Since China's accession to the WTO, its banking sector has been gradually opened to foreign influence. In December 2003 the Chinese government announced the US\$45 billion recapitalisation of the Bank of China and China Construction Bank so that they could be listed on the stock exchange and on August 26 and September 21, 2004, the two banks were respectively transformed into jointstock companies. Currently the China Industrial and Commercial Bank, the Agricultural Bank of China and the Bank of Communications are also preparing for public listing. 
In 2004, the PBC sped up the reform of rural credit cooperatives. Initial pilot programmes were carried out in 8 provinces, the success of which saw the State Council extend the reform to include another 21 provinces in the reform program, including Beijing, Tianjin and Hebei. By the end of 2004, the PBC, together with the China Banking Regulatory Commission (CBRC), had approved rural credit cooperatives in 620 counties to purchase in four groups central bank special bills totalling 35.55 billion yuan. Rural credit cooperatives included in this reform have experienced significant improvement in their financial situation with the mitigation of historical problems.

\subsection{The Evolution of the Credit Allocation System}

Prior to 1978 the allocation of credit was arranged through the PBC and its branches according to the credit plan, which was prepared in the form of a source-and-use-of-funds statement to match the estimated demand for physical resources. After establishing the two-tier banking system (central bank and specialised banks), the authorities revised the regulations in 1984 so that specialised banks were allowed a certain freedom in the use of funds and were responsible for profits and losses although they were still obliged to submit projections on loans and deposits to the PBC for approval. The credit quotas for the specialised banks were strictly enforced with the banks forbidden to extend credit that exceeded the ceiling.

During the 1980s the overall trend was away from direct controls and by 1990 only the SOBs remained subject to any credit quotas. It is interesting that, as the SOBs had become gradually more prudent in terms of credit allocation in the face of the deteriorating performance of the state owned enterprises (SOEs), only 80 percent of the credit quota was fulfilled by 1997 . The PBC finally removed credit quotas for the SOBs in 1998, moving instead to the implementation of management principles based on asset-liability ratios. Since February 2004, the PBC has begun to manage capital sufficiency to deal with operating and market risk in order to increase the capital base of the SOBs to the point of the capital adequacy requirements of the Basel Capital Accord.

\subsection{Interest Rate Deregulation}

China has taken a cautious approach to the deregulation of centrally controlled interest rates. During the pre-reform period, interest rates were controlled by the PBC and fixed at very low levels and rarely varied. Lin et al. (1998) have argued that such repression created several problems such as a severe shortage of capital and inefficient capital allocation.

In 1983 the PBC first allowed some interest-rate flexibility for the SOBs when floating interest rates were introduced for certain types of workingcapital loans. In 1986 banks were allowed to adjust lending interest rates within a certain margin about the administered rate, but such flexibility on deposit interest rates was not granted. In October 1993, following a decision by the 14th national congress of the Chinese Communist Party that "the central bank shall promptly adjust benchmark interest rates according to changes in market 
supply and demand, and allow the commercial banks to flexibly set their own rate on loans and deposit within a specified range", the PBC has taken steps to widen the floating band on lending rates for financial institutions and to adjust the reference rates more frequently, cutting the deposit and lending rates on nine occasions between May 1996 and October 2004. The PBC also began to set a reference rate for the inter-bank market in January 1996; the inter-bank bond market was launched in June 1997; and a market-based auction method began to be used in October 1999 for all government bonds.

More recently important steps have been taken to further advance the market-based interest rate reform with the band for lending rates of the financial institutions being further widened from the beginning of 2004. In October 2004, the upper limit on the loan rates charged by commercial banks was removed and that for the rural and urban credit cooperatives was raised to 2.3 times the benchmark rate. A lower limit was no longer applied to the interest rate of RMB deposits. Therefore, by late 2004 interest rates on both sides of bank balance sheets were largely market-determined.

\subsection{The financial regulatory system}

Given the history of central planning in China since 1949, it is not surprising that the development of the financial regulatory system experienced a proliferation of agencies and rules interrupted by several attempts to streamline and centralise the regulatory infrastructure.

The PBC as central bank was first designated as the key agent for financial market supervision in 1984 and officially retained this function until 1992. During this period the Bank exercised comprehensive regulatory as well as administrative jurisdiction over the financial sector. With the two major stock exchanges emerging in 1990, the State Council established the State Council Securities Commission (SCSC) in 1992 and it became an important body for developing policies for financial markets, although it did not become a fullblown regulator. This task was assigned to the Chinese Securities Regulatory Commission (CSRC), created by the State Council in 1993. The CSRC was given some lawmaking power and issued listing requirements as early as 1993. However, until the adoption of the Securities Law in 1999, and the strengthening of the CSRC through its merger with the SCSC in 1998, the State Council issued most of the path-setting rules and policies that govern financial markets, including the 1993 regulations on the management of stock exchanges and securities fraud, and the 1995 adoption of B share regulations.

Although the reallocation of control rights over securities markets from the PBC to the SCSC and eventually to the CSRC has not come without opposition, the CSRC eventually became the only regulatory and supervisory institution for securities markets in 1999.

In 1998 the China Insurance Regulatory Commission (CIRC) was entrusted with the supervision of insurance companies, including preparations for the opening of the insurance sector to foreign players. In April 2003 the China Banking Regulatory Commission (CBRC) was established to take over 
the regulatory function of the banking sector from the $\mathrm{PBC}$ in order to leave the PBC free to concentrate on monetary policy matters.

The reserve requirements system in China was established in 1984. The statutory reserve ratio was very high by the standards of developed financial markets. Initially, reserve ratios were set at different levels for different deposits: 20 per cent for enterprise deposits, 40 per cent for savings deposits and 25 per cent for rural deposits. The reserve requirements were unified and reduced to 10 per cent for all deposits in 1985 but increased to 13 per cent in 1987, a level which was maintained until 1998. In addition, the SOBs were required to hold excess reserves of around 5-7 per cent. The sum of these two ratios amounted to approximately 20 per cent. This high reserve ratio policy was reversed in 1998 when the PBC consolidated the statutory reserve account and excess reserve account to a single legal reserve account, and the legal reserve ratio was reduced from 13 per cent to 8 per cent. In 1999, the PBC further lowered the reserve ratio from 8 per cent to 6 per cent but it was raised by 1 percentage point to 7 per cent on September 21, 2003. In addition, the PBC also lowered the interest rate on excess reserves of financial institutions from 1.89 per cent to 1.62 per cent on December 21, 2003 in order to encourage financial institutions to more efficiently use their resources. The interest rate on statutory reserves was kept at 1.89 per cent. Thus by 2004 bank liquidity management by the central bank was proceeding along lines similar to those used in developed financial markets.

\subsection{Stock Market Development}

The development of China's stock market is one of the most important elements of China's reform of the financial system and China's stock market has experienced amazing growth since its beginnings in the early 1990s although its capitalisation still accounts for only a small part of total financial assets.

In July 1984 Beijing Tianqiao Department Store was the first company limited by shares in post-1949 China and in November of the same year the Shanghai FeiLe Acoustics Company issued irredeemable shares to the public. By the second half of the 1980s the issuing of equity had become increasingly frequent and shares began to change hands through non-market channels. Shenyang became the first city to initiate formal over-the-counter (OTC) trading in July 1986, followed by Shanghai two months later. By the end of 1988 there were nine financial institutions conducting OTC trading.

In December 1990 and July 1991, two stock exchanges, the Shanghai Stock Exchange and the Shenzhen Stock Exchange were established. Initially, there were only eight companies listed on the Shanghai Stock Exchange and six on the Shenzhen Stock Exchange. A unique feature of the Chinese stock market is the two types of shares, A shares and B shares traded on each exchange. A Shares are exclusively sold to Chinese nationals and trade is carried out in local currency. B shares, the first of which was listed on the Shanghai exchange in February 1992, are traded in foreign currencies (Hong Kong dollars in Shenzhen and US dollars in Shanghai) by foreign investors. Since February 2001, domestic investors are also allowed to trade in B shares, although trading is still restricted to be in 
terms of foreign currency. In addition to the A and B shares, Chinese companies can issue $\mathrm{H}$ shares on the Hong Kong Stock Exchange, $\mathrm{N}$ shares on the New York Stock Exchange and S shares on the Singapore Stock Exchange but these account for relatively little of their capitalisation.

In general, China's stock market is a policy-driven market. At the beginning of the 1990s, the stock markets grew largely because of promotion by local government bodies in Shanghai and Shenzhen while the central government paid little attention to stock market activity. This changed, however, from 1996 onwards; in 1997, the Government endorsed a plan to transform more than 10,000 SOEs into publicly listed companies. Later, many SOEs were listed but with a large proportion of their shares being non-tradable state-owned shares. Trading shares in companies which were still effectively government-owned proved predictably problematical and was addressed in June of 2001 when the State Council announced plans to reduce state share ownership. This, however, caused a significant decline in stock prices as investors feared the unloading of large parcels of government-owned shares and the State Council had to suspend the state-owned share reduction scheme a year later.

In order to increase the supply of funds to the domestic share market, the CSRC instituted the Qualified Foreign Institutional Investor (QFII) system in December of 2002 by which limited access was given to foreign investors in A shares. On June 25, 2004 China launched a new small and medium enterprises board on the Shenzhen Securities Exchange. On April 29, 2005, the CSRC announced the resumption of reforms to address the imbalance between tradable and non-tradable shares and by the end of 2006, $95 \%$ of the listed companies issuing A shares had at least begun participation in the reform process. State-owned share holdings are still substantial, however.

\subsection{External liberalisation and openness}

Until the beginning of reforms in 1978, China under Mao Zedong was largely closed to the outside world (with occasional exceptions of other communist countries) but since reform began it has gradually widened its economic relationships with the rest of the world although decision-making concerning external liberalisation has been highly centralised. All major policies in this area have been decided by the State Council and has involved four departments which, in the current government institutional setup are: the National Development and Reform Commission, the State Administration of Foreign Exchange (SAFE), the Ministry of Commerce, and the PBC.

The liberalisation process can be broken down into five phases: (i) early liberalisation from 1978 to 1986; (ii) a period of increased regulation from 1987 to 1991; (iii) re-accelerated liberalisation from 1992 to 1996; (iv) the strengthening of capital controls following the Asian financial crisis from 1997 to 2000; and (v) the post-WTO era from 2001 to the present.

In the first, early liberalisation, phase from 1978 to 1986 China maintained a dual exchange rate system until the beginning of 1985 when the rates were 
unified. Strict foreign exchange controls were in force during this period although they were relaxed for four coastal cities (Shenzhen, Zhuhai and Shantou in Guangdong province and Xiamen in Fujian province), initially selected by the authorities as foci to attract foreign direct investment (FDI) into the manufacturing sector; this group of cities was later extended to 14 coastal cities in 1984 and to the deltas of the Yangtze, Pearl and Minnan Rivers in 1985. In all cases the authorities allowed domestic firms and local governments to retain part of their foreign exchange earnings.

The second phase which ran from 1987 to 1991 was a period during which regulations were increased. An initial foreign exchange control and monitoring system was set up during this period. In 1988, the FDI policies were expanded to Hainan Island and another 140 coastal cities and counties, including Nanjin, Hangzhou and Shenyang. The official exchange rate in this period was adjusted several times in line with changes in purchasing power parity although adjustments of the official exchange rate generally lagged price changes. Effective 9 April 1991, the official exchange rate regime was changed from a periodical adjustment to a managed float, allowing the authorities to adjust the rate more frequently. In the face of high inflation in 1989, some rules and regulations were introduced to strengthen supervision and monitoring of external transactions including regulation of foreign-funded enterprises' foreign investment.

Following the strengthening of regulation in the late 1980s, the third phase saw a re-acceleration of liberalisation and of the opening-up process from 1992 to 1996. In 1992 the B-share market was launched on the Shenzhen and Shanghai stock exchanges, allowing foreign access to Chinese shares and on July 15, 1993 the first Chinese firm, Qingdao Beer, listed its shares on a foreign exchange - the Hong Kong Stock Exchange. In 1994, the foreign exchange retention and quota system was repealed and replaced by a foreign exchange surrender and purchase system which realised conditional current account convertibility. In late 1996 China moved to full current account convertibility.

The fourth phase began with the Asian financial crisis in the second half of 1997 which prompted the strengthening of capital controls and monitoring until 2000. Capital outflows became an increasing problem in late 1997 and early 1998. To prevent illegal capital outflows, the restrictions on financial institutions and enterprises permitted to provide external guarantees were significantly tightened in 1997. SAFE launched a targeted examination of import payments in 1998. In contrast to this regulatory tightening, 13 cities were opened to foreign banks in 1997 to conduct business in RMB and in 1999 the geographic restriction on foreign banks was repealed, although the geographic restrictions on foreign banks' conducting business in RMB were retained.

The fifth and final phase, the liberalisation of external economic relations, began with China's accession to the WTO and continues to the present. It has been a period of all-round external liberalisation in China. In the banking sector, foreign banks were allowed to provide foreign exchange services to all firms and individuals and provide RMB services to domestic firms in open cities from 
2003. In capital markets, domestic investors including individual residents are allowed to invest in B shares with self-owned foreign exchange earnings since 2001. From 2002 Qualified Foreign Institutional Investors (QFII) have been allowed to invest in the domestic capital (bond and stock) markets and since 2004 insurance companies have been allowed to use their own foreign exchange to invest in foreign capital markets. In 2005, the first foreign company was listed on the Shanghai Stock Exchange. In the same year, domestic firms were allowed to set up corporations abroad with the special purpose of facilitating overseas listing, mergers and acquisitions. In the foreign exchange market, the PBC continued RMB exchange system reform when, on April 21, the RMB was pegged to a basket of currencies and allowed to fluctuate within an extended range of 3 per cent.

\subsection{The improvement of the legal framework}

The legal framework is a tool to regulate the relationship among financial supervisors, financial institutions and investors in financial products in order to provide an environment in which laws are transparent and consistently enforced. Anecdotal evidence of widespread violation of these principles of good governance in Chinese financial markets has been persistent despite considerable advances made by the authorities in establishing and enforcing laws and regulations to control the financial system.

A large number of rules and regulations for the financial sector have been formulated since reform began in 1978. Laws such as the Law of the People's Bank of China (1995), the Commercial Banking Law (1995), the Insurance Law (1995), the Securities Law (1998), the Law on Trust and Investment Companies (2001), and the Law on Banking Regulation and Supervision (2003) which regulate financial supervision, financial institutions and their behaviour, have formed the fundamental legal framework for the financial sector.

The Law on Administrative Penalty (1999), the Law on Administrative Appeal (2003), and the Law on Administrative License (2003) are designed to regulate the administrative behaviour of financial supervisors. In addition, the Law on Negotiable Instruments (1995), the Guarantee Law (1995), and the Company Law (1993, revised in 1999, 2004 and 2005) are designed to regulate civil and commercial relations.

The PBC is maintaining its efforts to improve the legal framework for the financial sector with the current amendment of the Criminal Law, the Securities Law and the Enterprise Insolvency Law which were finished in 2006 and the Law on Anti-Money Laundering which came into effect in November 2006. In addition, the PBC is facilitating the formulation of the Regulations on Credit Information Management, the new Enterprise Insolvency Law, the Regulations on the Bankruptcy of Financial Institutions, the Regulations on Deposit Insurance and the Rules on Administration of the Securities Investor Protection Fund amongst other initiatives.

Despite this plethora of legislation and regulatory activity, it must be remembered that this is occurring with the context of a developing and emerging 
financial system during a period of rapid economic, financial and political transition. With the deepening of China's financial system, the accelerated opening-up to the rest of the world and the rapid innovations in the financial sector, the legal framework is barely able to keep pace with the changing requirements of the financial sector and great efforts will be required on the part of the authorities to bring China's financial system framework into the $21^{\text {st }}$ century.

In conclusion, there has been rapid, substantial and continual change in the Chinese financial system from 1978 onwards. We have described a system which less than 30 years ago consisted of a single government-owned bank and which has developed into a highly diversified, sophisticated system serving a dynamic economy with over 1.3 billion inhabitants. It may well be argued that there have been significant hiccups in the reform process and that there is still substantial development necessary before China has a smoothly functioning, transparent and modern financial system.

\section{The Financial liberalisation index}

The measurement of financial liberalisation in a form suitable for econometric investigation is problematical for at least two reasons: how can the process of financial liberalisation be measured numerically and how can the multidimensional nature of liberalisation be accommodated in a single or relatively few variables?

The most common response to the measurement problem has been to use readily observable financial variables such as the ratio of bank loans to GDP to represent liberalisation. Examples of this abound in the literature on the relationship between finance and growth reviewed briefly in section 1. While this may be an acceptable approach for the measurement of financial development (although see Levine, 2005, for an expression of concern about the gap between theory and measurement even here), for the purposes of measuring the extent of financial liberalisation it seems unsuitable. At best, it measures the outcome of the liberalisation process and not the process itself and, moreover, it is likely to be the outcome of the interaction between liberalisation and other economic factors.

An alternative resolution of the measurement problem is to examine the history of liberalisation itself and construct an artificial index of liberalisation by assigning numerical values to particular deregulatory events. While this is more likely to capture liberalisation as such, it will be plagued by a certain arbitrariness in the assignment of numbers to events. This difficulty notwithstanding, a similar approach has been widely used in the literature on institutions and growth to capture the evolution of the political environment (see Glaeser et al., 2004, for a recent example).

The second problem associated with the construction of a liberalisation variable is that of the multi-dimensional nature of liberalisation. Again, two alternative methods have been used in the face of this problem. The most 
common has been to use a single representative measure or a limited number of measures entered as regressors simultaneously. However, the results of using a single measure may be sensitive to choice of representative measure (although this weakness may be ameliorated by assessing the sensitivity of the results to the particular measure chosen) while the simultaneous use of multiple measures has been plagued with problems of multicollinearity given the inter-relatedness of different aspects of liberalisation.

A second approach has been to construct a variable which combines in a single measure the multiplicity of components. An early cross-country variable of this type measuring financial development (of the stock market) is one by Demirguc-Kunt and Levine (1996) in which they compute an index as a simple average of standardised measures of financial development such as market capitalisation/GDP, value traded/GDP and so on. An application of this approach is in a recent paper by Love (2003) who assesses the effects of financial development on individual firms' investment decisions.

In a similar approach but from a political-science perspective, Quinn (1997) constructed a financial liberalisation index from three components, focussing on openness of the balance of payments - one component covered the capital account, one the current account and one international legal agreements. Each component is captured by a sub-index which starts from 0 with 1 being added each time a significant incident of de-regulation is observed. The sub-indexes are combined by simply adding them. This index was used in subsequent work by Adsera et al. (2001), also focussing on political questions, in this case the determinants of government effectiveness and corruption. A later cross-country study of the determinants of liberalisation by Abiad and Mody (2005) used a similar but somewhat more sophisticated index - they combine 6 aspects and assign a value of $0,1,2$ or 3 to each country for each aspect depending on the magnitude of the deregulatory change. They aggregated the resulting subindexes by simply adding them together although they report that alternative aggregation schemes were tried but without substantial effects on the outcome.

Applications to questions of the economic effects of liberalisation have also used various ways to address the multiplicity problem ranging from a recent paper by Koo and Shin (2004) which simply uses a 0-1 dummy variable to more complex treatments by Laeven (2003) who used a simple addition of six 0-1 dummy variables, to Bandiera et al. (2000) who assign a 0 or 1 in each of eight categories but combine the resulting dummy variables using principalcomponents analysis to construct a single index of liberalisation. A similar approach is used by Koo and Maeng (2005) although they depart from the $0-1$ scheme and allocate an additional 1 for each period in which there was a significant liberalisation event.

There has, therefore, been general recognition that financial liberalisation is difficult to measure in a form suitable for econometric analysis and any approach will be less than ideal. We overcome the measurement problem by constructing sub-indexes for a variety of aspects of the liberalisation process. We attempt to overcome the subjectivity of the assignment of numbers to deregulatory events 
by using the Delphi method. This involved choosing 15 experts (a mixture of academics in the areas of finance and economics, commercial bankers, central bankers and government officials) and asking them to rate each of a set of eight aspects of liberalisation over the sample period, assigning a value between zero and one for each aspect for each year of the sample. The resulting 15 individual responses were averaged to derive a sub-index for each aspect ranging between zero at the beginning of the sample to one at the end for each aspect.

We analysed the individual responses to detect outliers and it was interesting (and reassuring) that the individual responses were highly correlated, indicating a high degree of common assessment of the regulatory changes over the period. The correlation matrix for the individual assignments for the first aspect, "Policy", is reported in Panel A of Table 1 while Panel B reports column averages for the first aspect in the first row and for the other seven aspects in the remaining rows. For the first aspect, it is clear that, with the exception of respondent 11, all responses are very highly correlated with correlation coefficients usually well over 0.9 and, from the remainder of Panel B, it is clear that respondent 11 is not a consistent outlier and that outliers even of this magnitude are rare. We are reasonably confident, therefore, that the responses are reflective of generally perceived changes in the regulatory structure of Chinese financial markets over the sample period.

The second problem we had to solve was the multi-dimensional nature of deregulation. It is clear from our discussion so far that we have chosen not to focus on one or a few easily measured proxies for liberalisation but have instead measured eight different aspects of the liberalisation process itself. They are:

- "policy": major central government policy shifts

- "institutions": the diversification of financial institutions,

- "allocation": the reform of credit allocation,

- "interest": interest rate deregulation,

- "regulations": the establishment of a financial regulatory system,

- "stock": the development of a stock market,

- "open": increased openness to the rest of the world, and

- "legal": the development of the financial legal framework.

Using all of these indexes in a regression model would doubtlessly lead to serious multicollinearity due to the likely inter-relationships between aspects of the liberalisation process. To use only one or a few would risk the problem of omitted variables. We therefore use an approach which has been used in some recent papers reviewed above, viz. principal-components analysis, to combine the eight indexes into one index which we denote FLI.

Principal-components analysis is a method of long standing to assess and summarise the common contents of a set of variables. Consider a set of $K$ variables $\boldsymbol{X}_{k}(k=1,2, \ldots, K)$, each with $T$ observations, combined in the matrix $\boldsymbol{X}$. The cross-products matrix $\boldsymbol{X}^{\boldsymbol{X}} \boldsymbol{X}$ has $K$ eigenvectors $\boldsymbol{a}_{k}$ and associated eigenvalues $\lambda_{k}$. If we arrange the eigenvectors and eigenvalues in decreasing order of magnitude of the eigenvalues we can define the $k$ th principal component of the $\boldsymbol{X}$ matrix as 
Table 1: Correlation of individual responses

\begin{tabular}{|c|c|c|c|c|c|c|c|c|c|c|c|c|c|c|}
\hline \multicolumn{15}{|c|}{ Panel A: Correlations for "Policy" } \\
\hline \multicolumn{15}{|c|}{1.000} \\
\hline 0.989 & 1.000 & & & & & & & & & & & & & \\
\hline 0.980 & 0.985 & 1.000 & & & & & & & & & & & & \\
\hline 0.983 & 0.989 & 0.980 & 1.000 & & & & & & & & & & & \\
\hline 0.979 & 0.988 & 0.953 & 0.981 & 1.000 & & & & & & & & & & \\
\hline 0.952 & 0.950 & 0.932 & 0.971 & 0.966 & 1.000 & & & & & & & & & \\
\hline 0.946 & 0.950 & 0.913 & 0.967 & 0.977 & 0.993 & 1.000 & & & & & & & & \\
\hline 0.940 & 0.974 & 0.935 & 0.957 & 0.913 & 0.923 & 0.944 & 1.000 & & & & & & & \\
\hline 0.943 & 0.942 & 0.936 & 0.978 & 0.957 & 0.989 & 0.979 & 0.929 & 1.000 & & & & & & \\
\hline 0.986 & 0.996 & 0.993 & 0.994 & 0.980 & 0.946 & 0.940 & 0.970 & 0.951 & 1.000 & & & & & \\
\hline 0.879 & 0.838 & 0.840 & 0.823 & 0.857 & 0.774 & 0.766 & 0.763 & 0.770 & 0.838 & 1.000 & & & & \\
\hline 0.950 & 0.976 & 0.965 & 0.934 & 0.957 & 0.941 & 0.930 & 0.812 & 0.906 & 0.961 & 0.862 & 1.000 & & & \\
\hline 0.977 & 0.998 & 0.972 & 0.977 & 0.996 & 0.953 & 0.960 & 0.888 & 0.943 & 0.990 & 0.871 & 0.974 & 1.000 & & \\
\hline 0.985 & 0.994 & 0.977 & 0.998 & 0.994 & 0.974 & 0.974 & 0.977 & 0.973 & 0.993 & 0.824 & 0.962 & 0.994 & 1.000 & \\
\hline 0.979 & 0.987 & 0.963 & 0.994 & 0.996 & 0.983 & 0.986 & 0.976 & 0.978 & 0.983 & 0.812 & 0.958 & 0.991 & 0.998 & 1.000 \\
\hline \multicolumn{15}{|c|}{ Panel B: Average correlation coefficients } \\
\hline 0.965 & 0.970 & 0.955 & 0.968 & 0.966 & 0.950 & 0.948 & 0.927 & 0.945 & 0.968 & 0.835 & 0.939 & 0.965 & 0.975 & 0.972 \\
\hline 0.967 & 0.975 & 0.969 & 0.975 & 0.982 & 0.947 & 0.969 & 0.907 & 0.967 & 0.971 & 0.972 & 0.979 & 0.980 & 0.980 & 0.978 \\
\hline 0.984 & 0.984 & 0.972 & 0.977 & 0.983 & 0.984 & 0.971 & 0.969 & 0.987 & 0.941 & 0.982 & 0.978 & 0.982 & 0.988 & 0.985 \\
\hline 0.971 & 0.985 & 0.974 & 0.974 & 0.981 & 0.971 & 0.982 & 0.972 & 0.974 & 0.972 & 0.981 & 0.976 & 0.976 & 0.983 & 0.971 \\
\hline 0.962 & 0.936 & 0.945 & 0.965 & 0.924 & 0.949 & 0.960 & 0.871 & 0.944 & 0.898 & 0.965 & 0.966 & 0.961 & 0.960 & 0.949 \\
\hline 0.973 & 0.973 & 0.965 & 0.976 & 0.888 & 0.963 & 0.962 & 0.958 & 0.970 & 0.936 & 0.970 & 0.962 & 0.963 & 0.955 & 0.967 \\
\hline 0.984 & 0.988 & 0.987 & 0.987 & 0.975 & 0.972 & 0.961 & 0.978 & 0.987 & 0.987 & 0.989 & 0.956 & 0.986 & 0.979 & 0.989 \\
\hline
\end{tabular}




$$
Z_{k}=X . a_{k}
$$

and the ratio $\left(\lambda_{k} / \sum \lambda_{k}\right)$ measures the proportional contribution of the $k$ th principal component to the total variation in the $\boldsymbol{X}$ variables. Thus if, as we shall find, the first principal component captures most of the variation in the $\boldsymbol{X}_{k} \mathrm{~s}$, we can use it to summarise the information in the data set. In cases where the first principal component does not include most of the variation in the data set, a single index may be constructed as a linear combination of the most important principal components.

In Table 2 we report the eigenvalues of the eight possible components as well as the proportion and the cumulative proportion of the variation in the variables explained by each. It shows that the first principal component explains by far the greatest proportion of the variation in the individual sub-indexes and that the first two principal components explain over $97 \%$ of total variation. We use a weighted average of the first two principal components as the FLI, with the weights being the proportion which each explains of total variation. In the last two columns of the table we report the loadings on the eight variables for the first two principal components (the elements of $\boldsymbol{a}_{1}$ and $\boldsymbol{a}_{2}$ ); they show that the first principal component is roughly a simple average of the eight variables while this is not true of the second. ${ }^{3}$

A graph of the first two principal components and the FLI is given in Figure 1 below. The graph makes it clear that the FLI is approximately equal to the first principal component and that the index increases steadily over the sample period.

Table 2: Eigenvalues and scores of principal components

\begin{tabular}{cccccc}
\hline $\begin{array}{c}\text { Component } \\
\text { /Variable }\end{array}$ & Eigenvalue & $\begin{array}{c}\text { \% of Variance } \\
\text { explained }\end{array}$ & $\begin{array}{c}\text { Cumulative } \\
\text { \% of variance } \\
\text { explained }\end{array}$ & $\begin{array}{c}\text { Score principal } \\
\text { component } 1\end{array}$ & $\begin{array}{c}\text { Score } \\
\text { principal } \\
\text { component } \\
2\end{array}$ \\
\hline 1 & 7.379 & 92.232 & 92.232 & 0.132 & 0.044 \\
2 & 0.411 & 5.134 & 97.366 & 0.134 & -0.052 \\
3 & 0.084 & 1.053 & 98.420 & 0.124 & 0.926 \\
4 & 0.057 & 0.714 & 99.134 & 0.129 & -0.691 \\
5 & 0.031 & 0.386 & 99.520 & 0.131 & -0.521 \\
6 & 0.016 & 0.204 & 99.724 & 0.134 & -0.125 \\
7 & 0.012 & 0.155 & 99.879 & 0.126 & 0.833 \\
8 & 0.010 & 0.121 & 100.000 & 0.132 & -0.341 \\
\hline
\end{tabular}

${ }^{3}$ Note that, for the purposes of the second, third and fourth columns, the numbers in the first column refer to the components, the $\mathbf{Z}_{\mathrm{k}} \mathrm{s}$ (of which there are a maximum of eight), whereas for the purposes of the last two columns the numbers in the first refer to the $\boldsymbol{X}_{k} \mathrm{~s}$. 
Figure 1: The Financial Liberalisation Index

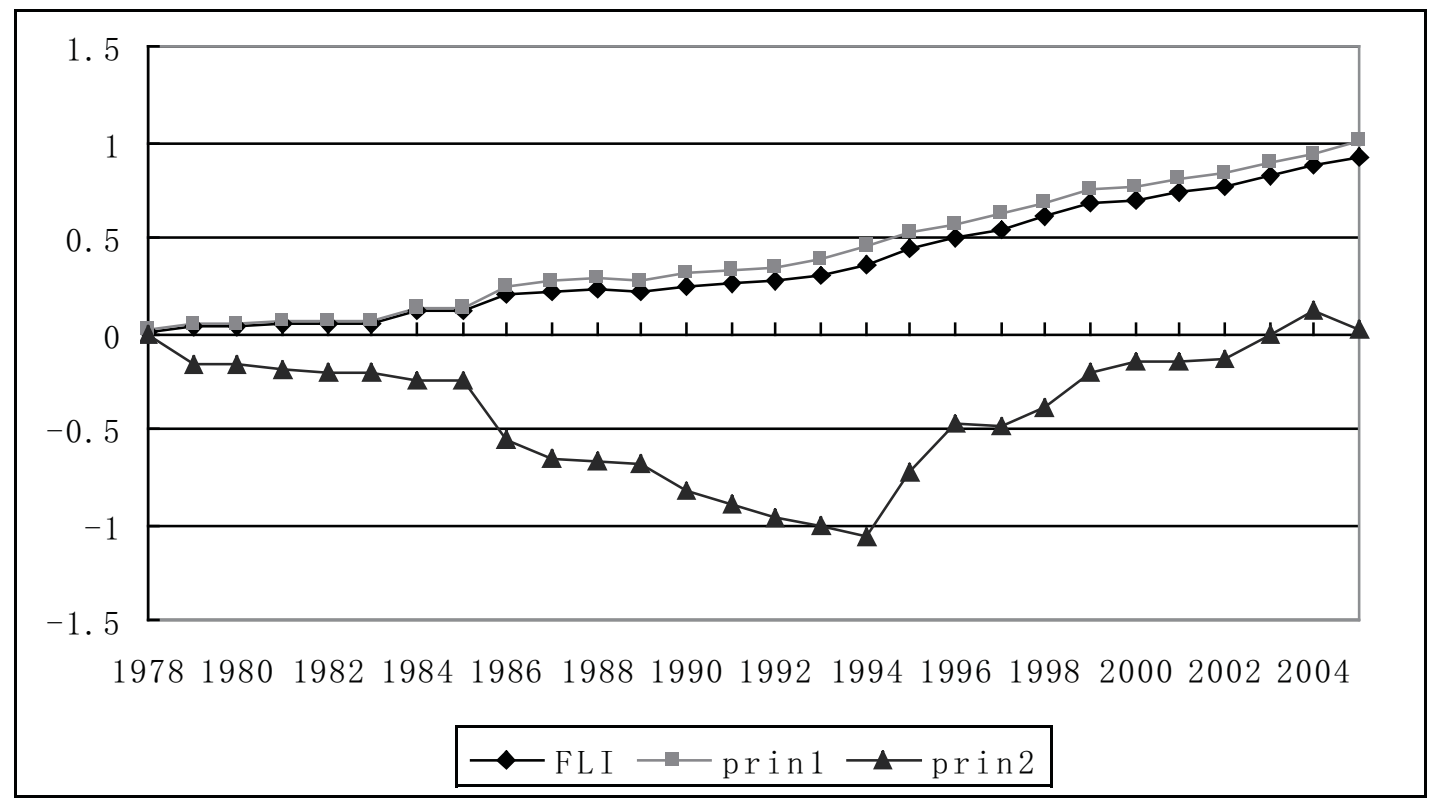

The FLI clearly increased monotonically over the sample period reflecting the general impression that reform is cumulative on the whole - while there may be particular reforms which are wound back (temporarily), the general thrust of reform of the financial system in China has been a continuing one. There have, however, been several episodes when reform appears to have accelerated (or, more precisely, has been perceived by the experts surveyed to have accelerated).

In the early years following the demise of Mao Zedong and the consolidation of power by Deng Xiaoping in 1978, reform seems to have proceeded slowly and cautiously. There was a spurt, however, starting in 1984 which reflects the establishment of the People's Bank of China as the central bank in April 1984. This event affected the FLI in various ways - through the credit control, institution building and prudential regulation components of the index. The establishment of the People's Bank also coincided with the institution of a system of statutory reserve requirements for the banks - the ratio was initially set very high but substantially reduced in 1985 .

Reform seems to have faltered somewhat between 1985 and the early 1990s. The first half of the 1990s saw steady institution building and diversification, relaxation and modernisation of the system of credit controls as well as the opening up of the financial system to the world economy with the move to a managed floating exchange rate. The brief reform spurt in 1998 coincided with the removal of direct credit controls, the consolidation of the system of reserve requirements and the greater flexibility in the way in which banks could set their interest rates. Finally, an acceleration of reform in the two last years of the sample reflects continued institution building, the further relaxation of interest rate controls and, in 2005, substantial changes to the foreign exchange arrangements. 
The overall behaviour of the index therefore looks plausible in the light of events in the Chinese financial system over the period.

\section{The causal relationship between financial liberalisation and development}

In this section we briefly consider the relationship between FLI and more common measures of financial development to assess our conjecture that liberalisation is likely to precede financial development. We use three measures of financial development commonly used in the literature: FIR (financial assets to GDP ratio), DEPTH (the ratio of M2 to GDP) and CREDIT (total credit to GDP ratio). The sample period for these is 1978 to 2005 as for the FLI and the data are taken from "China Statistical Yearbook" and "Almanac of China's Finance and Banking" (China Statistical Bureau, various years).

We analysed the relationship between our FLI and the three measures of financial development using a test for Granger causality. The test is straightforward and widely used. Thus, for example, to test whether FLI Granger-causes FIR we estimate an equation with FIR as the dependent variable and lagged values of each of FLI and FIR (and a constant) as regressors:

$F I R_{t}=\alpha+\beta_{l} F I R_{t-1}+\beta_{2} F I R_{t-2}+\ldots+\beta_{p} F I R_{t-p}+\delta_{l} F L I_{t-1}+\delta_{2} F L I_{t-2}+\ldots+$
$\delta_{p} F L I_{t-p}+\varepsilon_{t}$
and test the null hypothesis $\mathrm{H} 0: \delta_{1}=\delta_{2}=\ldots=\delta_{\pi}=0$, i.e. that FLI does not Granger-cause FIR. If the null hypothesis is rejected (i.e., $\delta_{1}$ to $\delta_{p}$ are jointly significant) we conclude that FLI Granger-causes FIR.

We chose lag length using standard criteria: the Akaike Information Criterion, the Schwarz Bayesian Criterion and the Hannan-Quinn Information Criterion. Generally three lags were indicated but in one case two seemed sufficient. We used three lags throughout but checked the robustness of the results by re-running all tests with one, two and four lags - our conclusions were unaffected.

Table 3 reports the results of tests of Granger causality between FLI and each of our three financial development variables in turn. In each case we can clearly reject the hypothesis that FLI does not Granger-cause the other variable but we cannot reject the hypothesis that the measure of financial development does not Granger-cause FLI. We therefore have strong evidence that our measure of financial liberalisation is causally prior to each of the common measures of financial development. This confirms our argument set out in the beginning of the paper that financial liberalisation precedes development and suggests that if we want to analyse the effects of finance on growth or other economic aggregates such as saving or investment we should start from financial liberalisation, especially if our interest in these questions is motivated by policy concerns. Moreover, the use of financial liberalisation measures is likely to be less plagued by endogeneity both because it is prior to development and because it is closer to policy changes which themselves are likely to be exogenous. While we would not argue for the complete replacement of financial development variables by financial liberalisation ones (for reasons also set out earlier in the paper), the use 
of the latter would clearly be an informative supplement to the current practice which concentrates on measures of financial development.

Table 3: Tests of Granger causality between FLI and financial development

\begin{tabular}{lrr}
\hline Variables & F statistic & p-value \\
\hline FLI $\rightarrow$ CREDIT & 4.0285 & 0.0247 \\
CREDIT $\rightarrow$ FLI & 0.5593 & 0.6491 \\
FLI $\rightarrow$ DEPTH & 3.2032 & 0.0497 \\
DEPTH $\rightarrow$ FLI & 2.2616 & 0.1182 \\
FLI $\rightarrow$ FIR & 13.6643 & 0.0001 \\
FIR $\rightarrow$ FLI & 1.0779 & 0.3849 \\
\hline
\end{tabular}

Notes: FLI is the financial liberalisation index described in the text, CREDIT is the ratio of total credit to GDP, DEPTH is the ratio of M2 to GDP and FIR is the ratio of total financial assets to GDP. The F-statistics are for a test that the first variable does not Granger-cause the second and the p-value is the corresponding marginal probability.

\section{Conclusions}

In this paper we have argued for the importance of the distinction between financial development and financial liberalisation. Financial liberalisation measures the process of government policy to deregulate the financial markets while financial development may be partly the effect of earlier financial liberalisation. In the literature which examines the links between finance and macroeconomic performance (mainly growth) the general practice is to use measures of financial development such as the ratio of bank deposits to GDP rather than a measure of financial liberalisation (which is typically much more difficult to construct). Nevertheless, financial liberalisation may be a preferable measure both because it is closer to the effects of deregulatory policy which often motivates the analysis and because it is less likely to be plagued by endogeneity problems.

To test our conjectures about the relationship between measure of liberalisation and development, we constructed an index of financial liberalisation for China for the period 1978 to 2005 . Our method of construction was based on an innovative combination of the Delphi method (by which we obtained information about liberalisation for a range of aspects of the financial system) and principal components analysis which we used to combine the various subindexes obtained from the Delphi procedure.

The resulting index was compared to three common measures of financial development by the use of Granger causality. Our results provided strong evidence that the index Granger-causes all three measures of financial development. There is no evidence of reverse causality.

We conclude that while empirical measures of financial liberalisation are more difficult to construct than most measures of financial development, they are 
likely to have a useful place in the analysis of the relationship between finance and economic aggregates such as growth because they are more closely related to policy which often motivates our interest in these questions and because, being causally prior to measures of financial development, they are less likely to be contaminated by endogeneity which has plagued the empirical literature on finance and growth (and, indeed, the empirical growth literature in general).

Author statement: Submitting author: Nicolaas Groenewold, University of Western Australia.e-mail: nic.groenewold@uwa.edu.au. He holds a visiting appointment at the Hunan Normal University. The authors are jointly responsible for any errors, and wish to thank the editorial office for the review and copy editing of the submission.

\section{References}

Abiad, A. and Mody, A. (2005), 'Financial Reform: What Shakes it? What Shapes it?', American Economic Review, 95, 66-88.

Adsera, A., Boix, C., Payne, M. (2001), 'Are You Being Served? Political Accountability and the Quality of Government', Inter-American Development Bank Research Department, Working Paper 438.

Allen, F., Qian, J. and Qian M. (2005), 'Law, Finance and Economic Growth in China', Journal of Financial Economics, 77, 57-116.

Bandiera, O., Caprio, G.., Honohan, P. and Schiantarelli, F., (2000), 'Does Financial Reform Raise or Reduce Saving?', Review of Economics and Statistics, 82, 239-263.

Bekaert, G., Harvey, C. and Lundblad, C. (2005), "Does Financial Liberalization Spur Growth?”, Journal of Financial Economics, 77, 3-55.

Demirguc-Kunt, A. and R. Levine (1996), "Stock Market Development and Financial Intermediaries: Stylised Facts", World Bank Economic Review, 10, 291-321.

Glaeser, E., La Porta, R., Lopez-de-Silanes, F., Shleifer, A., (2004), "Do Institutions Cause Growth," Journal of Economic Growth, 9, 271-303.

Goldsmith, R. W. (1969), Financial Structure and Development, Yale University Press, New Haven, USA.

Hao, C. (2006), 'Development of financial intermediation and economic growth: The Chinese experience', China Economic Review, 17, 347-362.

King, R. G.. and Levine, R. (1993), 'Finance and Growth: Schumpeter Might be Right', Quarterly Journal of Economics, 108, 717-738.

Koo, J. and Shin, S. (2004), 'Financial Liberalization and Corporate Investments: Evidence from Korean Firm Data', Asian Economic Journal, 18, 277292.

Koo, J. and Maeng, K. (2005), 'The Effect of Financial Liberalization on Firms' Investments in Korea', Journal of Asian Economics, 16, 281-297.

Laeven, L. (2003), 'Does financial liberalization reduce financing constraints?'

Financial Management, 32, 5-34. 
Levine, R, (2005), 'Finance and Growth: Theory and Evidence', Chapter 12 in P. Aghion and S. N. Durlauf (eds.), Handbook of Economic Growth, Volume 1A, Elsevier, 865-934.

Levine, R. and S. Zervos (1998), 'Stock Markets, Banks and Economic Growth', American Economic Review, 88, 537-558.

Li, K. W. and Liu, T. (2001), 'Financial Liberalization and Growth in China's Economic Reform', The World Economy, 24, 673 - 687.

Liang, Q. and Teng, J. Z. (2006), 'Financial Development and Economic Growth: Evidence from China', China Economic Review, 17, 395-411.

Lin, J. Y., Cai, F. and Li, Z. (1998), The China Miracle: Development Strategy and Economic Reform, the Chinese University Press, pp.198-201.

Liu, T. and Li, K. W. (2001), 'Impact of financial resources liberalization in China's economic growth: Provincial evidence', Journal of Asian Economics, 12, 245-262.

Quinn, D. (1997), 'The Correlates of Change in International Financial Regulation', American Political Science Review, 91, 531-551. 